\title{
Influence of Fertilizers on Soils Used for Oleaginous Crop
}

\author{
NARCIS BARSAN ${ }^{1}$, ALEXANDRA DANA CHITIMUS ${ }^{1 *}$, OANA-MARIA MUSCALU (PLESCAN) ${ }^{1,2}$, \\ FLORIN MARIAN NEDEFF ${ }^{1}$, ION SANDU ${ }^{3,4}$, ELENA PARTAL ${ }^{5}$, ANDREI VICTOR SANDU ${ }^{4,6}$, \\ MIRELA PANAINTE LEHADUS ${ }^{1 *}$ \\ ${ }^{1}$ Vasile Alecsandri University of Bacau, Faculty of Engineering, 157 Calea Marasesti, 600115, Bacau, Romania \\ ${ }^{2}$ Romanian Waters - National Administration of Siret Basin, 1 Cuza Voda Str., 600274, Bacau, Romania \\ ${ }^{3}$ Alexandru Ioan Cuza University of Iasi, Arheoinvest Interdisciplinary Platform, Scientific Investigation Laboratory, 11 \\ Carol I Blvd., 700506, Iasi, Romania \\ ${ }^{4}$ Romanian Inventors Forum, 3 Sf. Petru Movila Str., Bloc L11, III/3, 700089, Iasi, Romania \\ ${ }^{5}$ National Agricultural Research and Development Institute of Fundulea, Calarasi, 1 Nicolae Titulescu Str., 915200, \\ Fundulea, Romania \\ ${ }^{6}$ Gheorghe Asachi Technical University of Iasi, Materials Science and Engineering Faculty, 53A D. Mangeron Blvd., \\ 700050, Iasi, Romania
}

The main objective of the current research is to determine the influence of some soil fertilizations systems on the variation of the content of magnesium, aluminium, potassium, chromium and manganese from the soil. The experiments have been carried out in a experimental field, for a soil cultivated with oleaginous crop. In the case when was applied the variant fertilizations with farmyard manure was registered the higher values of the nutrients content in soil like magnesium, potassium and manganese.

Keywords: magnesium, aluminum, potassium, chromium and manganese, fertilizations systems, oleaginous crop

To maximize their productive potential, cultivated plants need adequate amounts of water, light, carbon dioxide and mineral nutrients (nitrogen, phosphorus, potassium, calcium, magnesium, sulphur and several microelements) [19]. Soil is the main source of mineral nutrients and water for plants. Its ability to provide the nutrients needed for plants varies depending on its fertility level [3, 4, 10-18].

The removal of nutrients from the soil by their absorption in the plant, by leachate or by other processes related to the natural dynamics of the soils, attract after them the decrease of the contents of mobile forms of the nutrients and the gradual decline of the production capacity of the soil [3, 4, 12, 19-24]. For these reasons, it is an objective necessity to compensate by applying mineral and organic fertilizers, both for consumption with crops and decrease of nutrient mobility through natural processes $[12,24,25]$.

According to the data presented in the Code of good agricultural practices, $36.5 \mathrm{~kg}$ of nitrogen, $17.5 \mathrm{~kg}$ of phosphorus and $50 \mathrm{~kg}$ of potassium, active substances are required to produce a ton of oleaginous crop seeds and strains [3, 4, 24, 25-37].

A particularity of the oleaginous crop culture is that if during the first three - five weeks of development it suffers due to the lack of nitrogen the losses of production cannot be recovered. Therefore, it is important that the plant, at the time of outgrowth, find the soil well supplied with nutrients. Well supplied, however, does not mean to abuse it, to turn crop fertilization into water pollution $[1,5,7,9,11,17]$.

It is important to keep in mind that oleaginous crop, compared to wheat and corn, reacts less efficiently to the application of chemical fertilizers. Therefore, excellent results can be obtained if natural fertilizers are used in the mentioned quantities $[3,4,6,8,10,12,24,28]$.

The purpose of this research has been to determine the influence of soil fertilizations systems on the chemical properties of soil (magnesium, aluminum, potassium, chromium and manganese) for a monoculture of oleaginous crop.

\section{Experimental part}

The study has been carried out in the experimental field of National Agricultural Research and Development Institute - Fundulea, Romania, for an oleaginous crop culture. [3, 4, 12, 30].

The experimental variants carried out at INCDA have been of the following type, figure $1[3,4,12,30]$ :

- oleaginous crop culture (Factor a): $a_{1}$.

- fertilization (Factor $b$ ): $b_{1}-b_{5}$. 


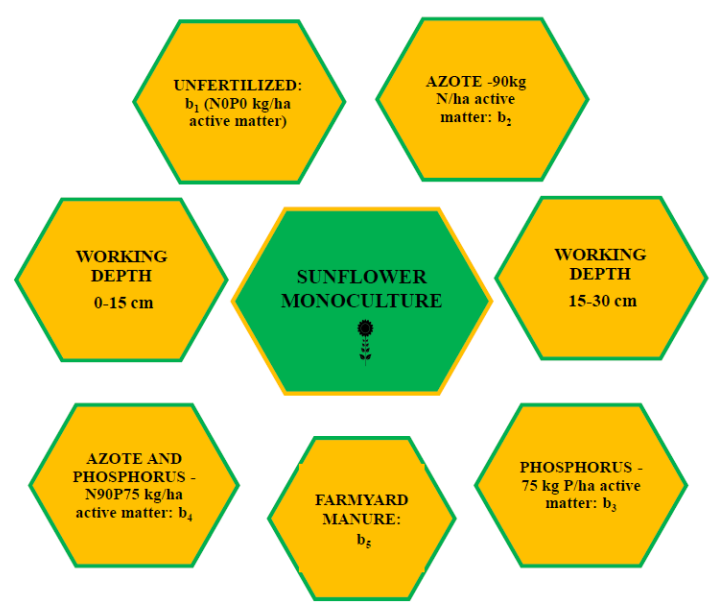

Fig. 1. The experimental variants carried out at INCDA $[3,4,12,30]$

Soil samples have been taken at the level of the year 2017, and they followed the determination of the content of magnesium, aluminium, potassium, chromium and manganese in the soil.

The content of magnesium, aluminium, potassium, chromium and manganese in the soil samples has been determined by using atomic absorption spectrometer (AAS), ZEENIT AAS version [38].

\section{Results and discussions}

The content of magnesium, aluminium, potassium, chromium and manganese of the soil samples taken on the unfertilized oleaginous crop parcel (control sample) are present in Table 1.

Table 1

THE CONTENT OF MAGNESIUM, ALUMINIUM, POTASSIUM,

CHROMIUM AND MANGANESE OF THE SOIL SAMPLES TAKEN ON THE

UNFERTILIZED OLEAGINOUS CROP PARCEL (CONTROL SAMPLE)

\begin{tabular}{|c|c|c|c|c|c|}
\hline \multirow{2}{*}{$\begin{array}{c}\text { Depth } \\
{[\mathbf{c m}]}\end{array}$} & $\mathbf{M g}$ & $\mathbf{A l}$ & $\mathbf{K}$ & $\mathbf{C r}$ & $\mathbf{M n}$ \\
\cline { 2 - 6 } & \multicolumn{5}{|c|}{$[\mathbf{m g} / \mathbf{k g ~ d . m .}]$} \\
\hline $0-15$ & 657 & 459.0 & 1157 & 10.6 & 105.5 \\
\hline $15-30$ & 627 & 421.2 & 978.7 & 15.7 & 95.6 \\
\hline
\end{tabular}

In the case of parcel fertilized with nitrogen ( $90 \mathrm{~kg} \mathrm{~N} / \mathrm{ha}$ ) the magnesium content was $69.1 \%$ of the value registered in the unfertilized soil parcel for the $0-15 \mathrm{~cm}$ depth, respectively by $88.67 \%$ of the control sample for the $15-30 \mathrm{~cm}$ depth (Fig. 2).

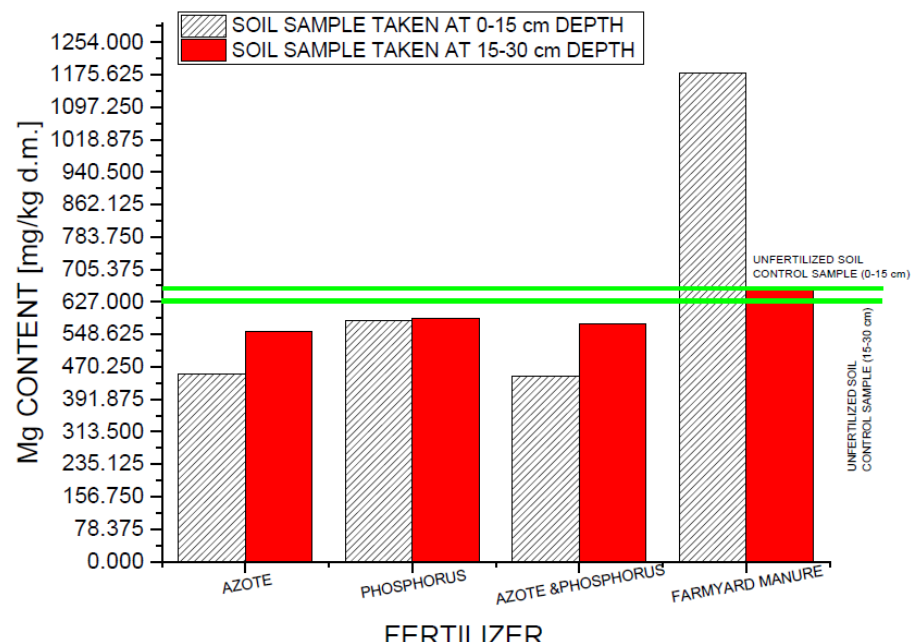

Fig. 2. Magnesium content in soil parcels fertilized with nitrogen, phosphorus, nitrogen and phosphorus, farmyard manure, for the $0-15 \mathrm{~cm}$ and 15-30 cm work depths

FERTILIZER

When was applied the experimental oleaginous crop variants - fertilized with phosphorus $(75 \mathrm{~kg} \mathrm{P} / \mathrm{ha})$ the soil magnesium content was: $88.43 \%$ of the value registered on the unfertilized soil parcel for the $0-15 \mathrm{~cm}$ depth, and $93.62 \%$ of the value registered on than the control sample, for the $15-30 \mathrm{~cm}$ depth.

The variations of magnesium content for the experimental variant - $a_{1} b_{4}$ was with $31.96 \%$ lower than the valued registered in the soil control sample value, in the case of $0-15 \mathrm{~cm}$ work depth, and with $27.7 \%$ lower the than valued registered in the soil control sample value, for the $15-30 \mathrm{~cm} \mathrm{~cm}$ work depth.

For the experimental variant $-a_{1} b_{5}$, the content of magnesium varied over the valued registered in the soil sample with no fertilization sequence applied: with $179.75 \%$ for the $0-15 \mathrm{~cm}$ work depth, and with $105.1 \%$ higher than the valued registered in the soil sample, for the $15-30 \mathrm{~cm}$ work depth. 
Variation of the aluminium content (Fig. 3) in case of the nitrogen fertilized parcel was $65.55 \%$ of the control sample value for the $0-15 \mathrm{~cm}$ depth. In the case of work depth $15-30 \mathrm{~cm}$ the variation of the aluminium content was under the value registered in the unfertilized soil parcel ( $73.74 \%$ of soil sample).

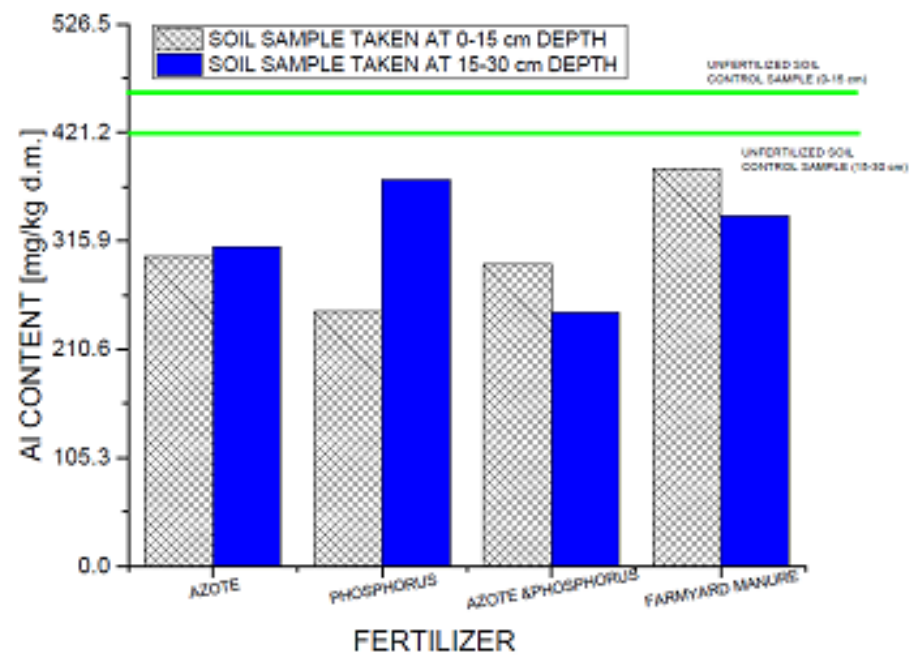

Fig. 3. Aluminium content on soil parcels fertilized with nitrogen, phosphorus, nitrogen and phosphorus, farmyard manure for the $0-15 \mathrm{~cm}$ and $15-30 \mathrm{~cm}$ depths

For the experimental variant $-a_{1} b_{3}$, the content of aluminium varied under the valued registered in the soil sample, respectively $53.87 \%$ of the control sample value, for the $0-15 \mathrm{~cm}$ depth, and $89.05 \%$ of the control sample value for the $15-30 \mathrm{~cm}$ depth.

Variation of the aluminium content for the experimental variant - $a_{1} b_{4}$, was under the valued registered in the soil sample, respectively for the work depth $0-15 \mathrm{~cm}$ was $63.81 \%$ of soil sample, and $58.38 \%$ of soil sample for the work depth $15-30 \mathrm{~cm}$.

When was applied the experimental oleaginous crop variants - fertilized with farmyard manure $\left(b_{5}\right)$, the soil aluminium content was under the value registered on the control sample for the both work depth, respectively $15.96 \%$ lower, for the work depth 0-15 cm, and 19.3\% lower for the work depth $15-30 \mathrm{~cm}$.

Figure 4 present the variations of potassium content for all the experimental variants analyzed, respectively:

- in the case of $a_{1} b_{2}$ experimental variant the variations of potassium content was under the value registered on the control sample, for the both work depth:

- 0-15 cm: $13.94 \%$ lower than the control sample;

- 15-30 cm: $15.7 \%$ lower than the control sample;

- for the experimental variant $a_{1} b_{3}$ the potassium content was under the value registered on the control sample, respectively $15.01 \%$ lower, for the work depth $0-15 \mathrm{~cm}$, and $19.28 \%$ lower for the work depth $15-30 \mathrm{~cm}$.

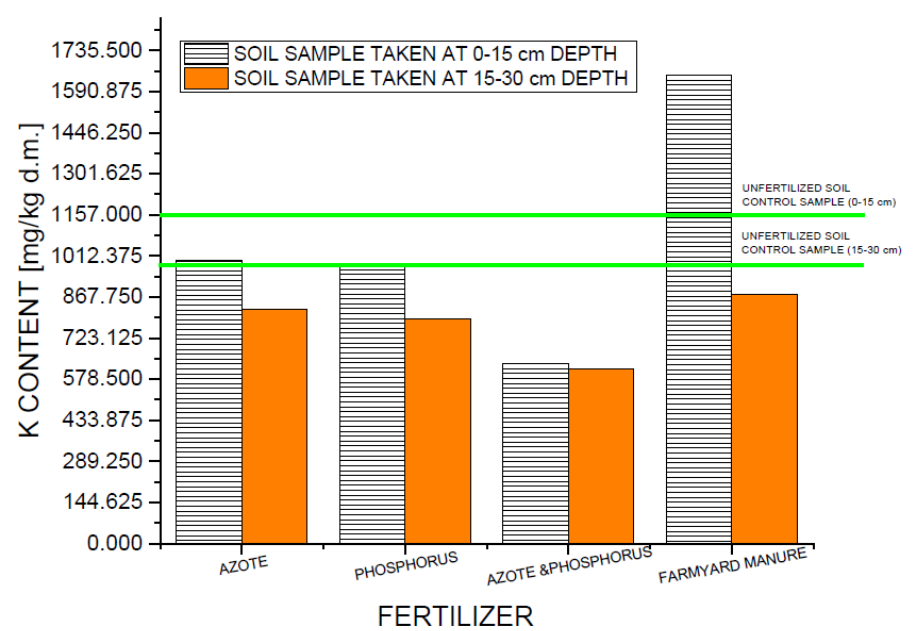

Fig. 4. Potassium content on soil parcels fertilized with nitrogen, phosphorus, nitrogen and phosphorus, farmyard manure for the $0-15 \mathrm{~cm}$ and $15-30 \mathrm{~cm}$ depths

- content of potassium for $\mathrm{a}_{1} \mathrm{~b}_{4}$ experimental variant was under the value registered on the control sample:

- 0-15 cm: 45.19\% lower than the control sample;

$\bullet 15-30 \mathrm{~cm}: 37.06 \%$ lower than the control sample;

- in the case of $a_{1} b_{5}$ experimental variant the variations of potassium content was over the value registered on the control sample, for the work depth $0-15 \mathrm{~cm}$, respectively with $142.52 \%$ higher than the valued registered in the soil sample with no fertilization sequence, and under the value registered on the control sample for the work depth 15-30 $\mathrm{cm}$, respectively with $10.41 \%$ lower than the valued registered in the soil sample with no fertilization sequence.

In the case of parcel fertilized with nitrogen $(90 \mathrm{~kg} \mathrm{~N} / \mathrm{ha})$, the variation of chromium content was under the value registered in the unfertilized soil parcel, respectively $48.11 \%$ lower than the value registered in the soil sample, for the 
0-15 cm work depth, and with $5.73 \%$ lower than the value registered in the unfertilized soil parcel, for the $15-30 \mathrm{~cm}$ work depth (Fig. 5).

When was applied the experimental variant $-a_{1} b_{3}$ the soil chromium content was under the value registered on soil sample, respectively $42.45 \%$ lower than the value registered on the unfertilized soil parcel for the $0-15 \mathrm{~cm}$ depth, and with 3.82\% lower than the value registered on than the soil sample, for the $15-30 \mathrm{~cm}$ depth.

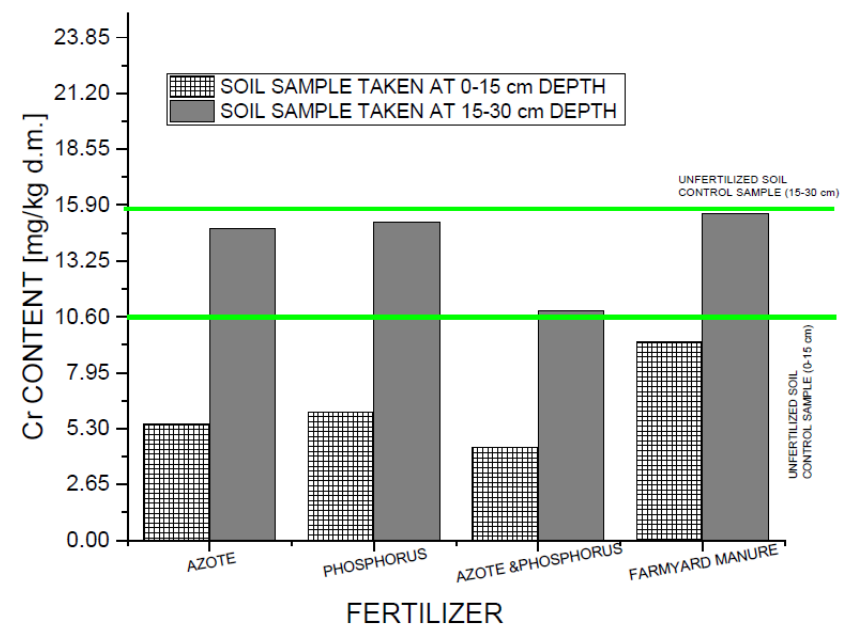

Fig. 5. Chromium content on soil parcels fertilized with nitrogen, phosphorus, nitrogen and phosphorus, farmyard manure for the $0-15 \mathrm{~cm}$ and $15-30 \mathrm{~cm}$ depths

The variations of chromium content for the experimental variant $-a_{1} b_{4}$, was under the value registered on the control sample, for the both work depth, respectively with $58.49 \%$ lower than the valued registered in the soil control sample value, in the case of 0-15 cm work depth, and with $30.57 \%$ lower the than valued registered in the soil control sample value, for the $15-30 \mathrm{~cm} \mathrm{~cm}$ work depth.

For the experimental variant - $a_{1} b_{5}$, the content of chromium varied under the valued registered in the soil sample with no fertilization sequence applied: lower with $11.32 \%$ for the $0-15 \mathrm{~cm}$ work depth, and lower with $1.21 \%$ for the $15-30 \mathrm{~cm}$ work depth.

Figure 6 present the variations of manganese content for all the experimental variants analyzed, respectively:

- in the case of $a_{1} b_{2}$ experimental variant the variations of manganese content was under the value registered on the control sample for the both work depth, the lowest value registered was for the work depth $15-30 \mathrm{~cm}: 70.08 \%$ of the soil control sample;

- for the experimental variant $a_{1} b_{3}$ the manganese content was under the value registered on the control sample, the lowest value registered was for the work depth $0-15 \mathrm{~cm}$ respectively $91.27 \%$ of the soil control sample value;

- content of manganese for $\mathrm{a}_{1} \mathrm{~b}_{4}$ experimental variant was under the value registered on the control sample:

- $0-15 \mathrm{~cm}: 57.44 \%$ of the control sample;

$\bullet 15-30 \mathrm{~cm}$ : $61.40 \%$ of the control sample;

- in the case of $a_{1} b_{5}$ experimental variant, the variations of manganese content was over the value registered on the control sample for the work depth $0-15 \mathrm{~cm}$, respectively with $129.47 \%$ higher than the valued registered in the soil sample with no fertilization sequence, and under the value registered on the control sample for the work depth 15-30 $\mathrm{cm}$, respectively with $2.1 \%$ lower than the valued registered in the soil sample with no fertilization sequence.

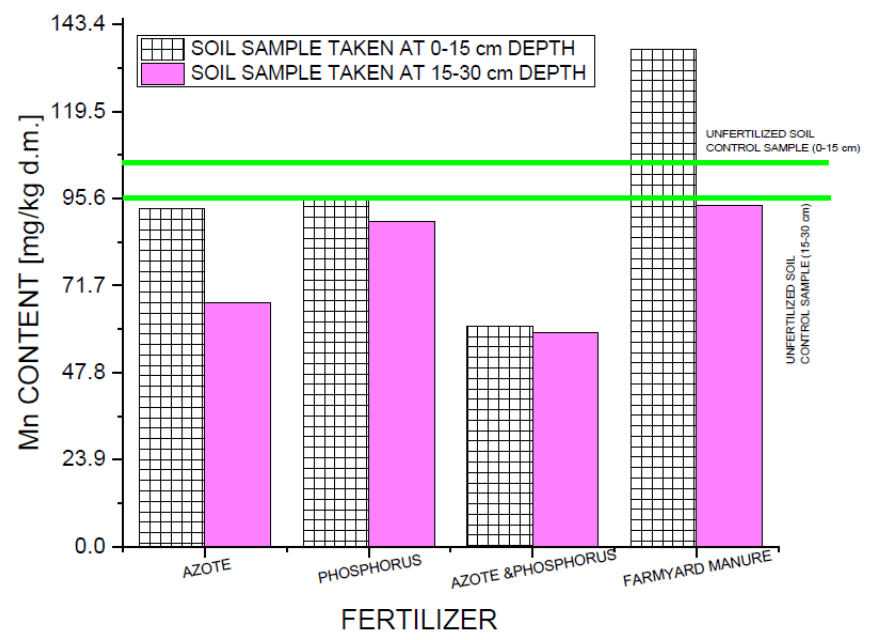

Fig. 6. Manganese content on soil parcels fertilized with nitrogen, phosphorus, nitrogen and phosphorus, farmyard manure for the $0-15 \mathrm{~cm}$ and $15-30 \mathrm{~cm}$ depths 


\section{Conclusions}

In this research it can be observed that the fertilizations systems with farmyard manure applied, were the best, because the content of nutrient in the soil grew up, in the case of magnesium, potassium and manganese, in especially for the work depth $0-15 \mathrm{~cm}$.

The content of magnesium from soil when was applied the fertilizations systems with nitrogen, phosphorus, nitrogen and phosphorus, was under soil sample value $(447 \mathrm{mg} / \mathrm{kg} \mathrm{d} . \mathrm{m} \div 587 \mathrm{mg} / \mathrm{kg} \mathrm{d}$.m.) In case of fertilizations systems with farmyard manure the content of magnesium from soil was higher than the control sample $(1181 \mathrm{mg} / \mathrm{kg}$ d.m for the level $0-15 \mathrm{~cm}$ ).

In case of aluminium and chromium, all the value registered in the soil, was under soil sample value, for all the fertilizations systems applied $(245.9 \div 285.7 \mathrm{mg} / \mathrm{kg} \mathrm{d}$.m. for aluminium and $4.4 \div 15.51 \mathrm{mg} / \mathrm{kg} \mathrm{d}$.m. for chromium).

The content of potassium and manganese from soil was higher than the control sample, only when was applied the fertilizations systems with farmyard manure for the level $0-15 \mathrm{~cm}(142.52 \%$ for potassium and $129.47 \%$ for manganese).

\section{References}

1.SANGAR, K., RIFAT, H., MUHAMMAD, S.F., QAISER, H., NOSHEN, A.A., Advances in Crop Science and Technology, 6, no. 1, 2017, p. $1-5$.

2.UZOMA, K.C., INOUE, M., ANDRY, H., FUJIMAKI, H., ZAHOOR, A., NISHIHARA, E., Soil Use and Management, 27, no. 2, 2011, p. 205.

3.MUSCALU (PLESCAN), O.M., NEDEFF, V., CHITIMUS, A.D., PARTAL, E., MOSNEGUTU, E., RUSU, I.D., Rev. Chim. (Bucharest), 69, no. 11,2018 , p. 3106-3111.

4.MUSCALU (PLESCAN), O.M., NEDEFF, V., PARTAL, E., MOSNEGUTU, E., SANDU, I.G., SANDU, I., BARSAN, N., RUSU, D., Rev. Chim. (Bucharest), 70, no. 5, 2019, p. 1726-1730.

5.BELCIU, M.C., NEDEFF, V., CHITIMUS, A.D., RADU, C., Journal of Engineering Studies and Research, 20, no. 1, 2014 , p. $23-32$.

6.ADAMIAK, E., ADAMIAK, J., Acta Scientarum Polonorum Agricultura, 14, no. 1, 2015, p. 3-10.

7.CHITIMUS, D., COCHIORCA, A., NEDEFF, V., MUSCALU, O., BARSAN, N., Proceeding of the International Multidisciplinary Scientific GeoConference Surveying Geology and Mining Ecology Management, SGEM, 18, 2018, p. 671-678.

8.RASHID, A., EJAZ, A.W, ASHRAF, M.Y., SHAMIM, A., TARIQ, A., Journal of Plant Nutrition, 37, no. 11, 2014 , p. $942-963$.

9.CHITIMUS, A.D., NEDEFF, V., MOSNEGUTU, E.F., PANAINTE, M., Environmental Engineering and Management Journal, 11, no. 12, p. 2163-2168.

10.SCHERER, H.W., METKER, D.J., WELP, G., Soil and Environment, 57, vol. 11, 2011, p. 513-518.

11.BELCIU, M.C., NEDEFF, V., CHITIMUS, A.D., BARSAN, N., RUSU, D., Journal of Engineering Studies and Research, 22, no. 1, 2016, p. $15-23$.

12.MUSCALU (PLESCAN), O.M., NEDEFF, V., CHITIMUS, A.D., PARTAL, E., BARSAN, N., RUSU, I.D., Rev. Chim. (Bucharest), 70, no. 2, 2019, p. 536-542.

13.SCHUlTZ, E., DESUTTER, T., SHARMA, L., ENDRES, G., ASHLEY, R., BU, H., MARKELL, S., KRAKLAU, A., FRANZEN, D., Agronomy Journal, 110, vol. 2, p. 685-695.

14.BELCIU, M.C., MOSNEGUTU, E.F., NEDEFF, V., CHITIMUS, A.D., BARSAN, N., FIORE, S., Environmental Engineering and Management Journal, 15, vol. 9, 2016, p. 2057-2062.

15.BELAY, A., CLAASSENS, A.S., WEHNER, F.C., Biology and Fertility of Soils, 35, no. 6, 2002, p. 420-427.

16.CHITIMUS, A.D., NEDEFF, V., LAZAR, G., Journal of Engineering Studies and Research, 17, vol. 4, 2011, p. $24-31$.

17.ADEBAYO, A.G, AKINTOYE, H.A., OLATUNJI, M.T., SHOKALU, A.O, AINA O.O., Report and Opinion, 2, vol. 4, 2010 , p. $29-33$.

18.CHITIMUS, A.D., RADU, C., NEDEFF, V., MOSNEGUTU, E., BARSAN, N., Scientific Study \& Research Chemistry \& Chemical Engineering, Biotechnology, Food Industry, 17, vol. 4, 2016, p. 383-393.

19.CHITIMUS, A.D., BARSAN, N., NEDEFF, V., MOSNEGUTU, E., MUSCALU (PLESCAN), O., 17th International Multidisciplinary Scientific GeoConference SGEM, 17, vol. 51, 2017, p. 859-866.

20.CLEMENS, S., PALMGREN, M.G., KRAMER, U., Trends in Plant Science, 7, vol. 7, 2002, p. 309-315.

21.WAJID, N., ASHFAQ, A., ASGHARI, B., RABIU, O., MUHAMMAD, U., TASNEEM, K., AFTAB, W., HAFIZ, M.H., MUHAMMAD, M., MUZZAMMIL, H., American Journal of Plant Sciences, 3, vol. 2, 2012, p. 243-251.

22.RADU, C., CHITIMUS, A.D., TURCU, M., ARDELEANU, G., BELCIU, M., Environmental Engineering and Management Journal, 13, vol. 7, 2014, p. 1687-1691.

23.RADU, C., NEDEFF, V., CHITIMUS, A.D., Journal of Engineering Studies and Research, 19, vol. 2, 2013, p. 89-96.

24.MONTEMURRO, F., GIORGIO, D., Journal of Plant Nutrition, 28, vol. 2, 2005, p. 335-350.

25.THAVAPRAKASH, N., SIVA, K.S.D., RAJA, K., SENTHIL K.G., Helia, 25, vol. 37, 2002, p. 59-68.

26.CHITIMUS, A.D., MOSNEGUTU, E.F., NICOLESCU, M.C., TURCU, M., BELCIU, M., ARDELEANU, G., Environmental Engineering and Management Journal, 13, vol. 7, 2014, p. 1581-1856.

27.CHITIMUS, A.D., NEDEFF, V., SANDU, I., RADU, C., MOSNEGUTU, E., SANDU, I.G., BARSAN, N., Rev. Chim. (Bucharest), 70, no.7, 2019, p. 2545-2551.

28.GIORGIO, D, MONTEMURRO, F., Helia, 30, vol. 47, 2007, p. 5-26.

29.CHITIMUS, A.D., NEDEFF, V., SANDU, I., RADU, C., MOSNEGUTU, E., SANDU, I.G., BARSAN, N., Rev. Chim. (Bucharest), 70,no. 8, 2019, p. 3058-3061.

30.MUSCALU (PLESCAN), O.M., NEDEFF, F.M., PARTAL, E., MOSNEGUTU, E., PANAINTE-LEHADUS, M., IRIMIA, O., TOMOZEI, C., Scientific Study \& Research Chemistry \& Chemical Engineering, Biotechnology, Food Industry, 20, no. 4, 2019, p. 585 - 595.

31.ARDELEANU, G., TOMOZEI, C., IRIMIA, O., PANAINTE-LEHADUS, M., 16th International Multidisciplinary Scientific GeoConference SGEM 2016, SGEM 2016 Conference Proceedings, 3, no. 2, 2016, p. 763.

32.IRIMIA, O., TOMOZEI, C., PANAINTE LEHĂDUŞ, M., MOSNEGUTU, E., BARSAN, N., Environmental Engineering and Management Journal, 12, no. 1, 2013, p. 35-39.

33.GOLDAN, E., NEDEFF, V., BARSAN, N., MOSNEGUTU, E., SANDU, A.V., PANAINTE, M., Rev. Chim. (Bucharest), 70, no. 3, 2019 , p. 809- 813. 
34.GOLDAN, E., NEDEFF, V., SANDU, I., BARSAN, N., MOSNEGUTU, E., MIRELA PANAINTE, Rev. Chim. (Bucharest), 70, no. 6, 2019, p. $2192-2197$.

35.IOSOB, G.A., NEDEFF. V., SANDU, I., CRISTEA, T.O., PRISECARU, M., SANDU, I.G., Rev. Chim. (Bucharest), 70, no. 9, 2019, p. 3262-3266.

36.IOSOB, G.A., NEDEFF, V., SANDU, I., PRISECARU, M., CRISTEA, T.O., Rev. Chim. (Bucharest), 70, no. 4, 2019 , p. $1416-1419$.

37.MUSCALU (PLESCAN), O.M., NEDEFF, F.M., PARTAL, E., MOSNEGUTU, E., PANAINTE LEHADUS, M., IRIMIA, O., TOMOZEI,

C., Scientific Study \& Research Chemistry \& Chemical Engineering, Biotechnology, Food Industry, 20, no. 4, 2019 , p. 585 - 595.

38.***Atomic absorption spectrometry (AAS) ZEEnit 700, Operating Manual, 2009.

Manuscript received: 20.12 .2019 